体力科学 (1997) 46, 93 100

\title{
ペダリング運動における収縮期血圧の応答
}

小原 繁* 林 美代子** 荒木 秀 夫 $^{*}$

\section{SYSTOLIC BLOOD PRESSURE RESPONSES TO PEDALLING EXERCISE}

\author{
Shigeru Obara, Miyoko Hayashi and Hideo Araki
}

\begin{abstract}
The response of systolic blood pressure (SBP) to pedalling exercise was studied in 32 healthy young men. The subjects performed the exercise at different intensities for 3 min using an incremental loading method. The first work load was $30 \mathrm{~W}$ and increased by $30 \mathrm{~W}$ until the heart rate (HR) reached about $170 \mathrm{bpm}$. SBP at HR 100 160 bpm (SBP@HR 100 160) was calculated from the cubic regression equation in each subject. Mean SBP and SEM at HR 100, 110, 120, 130, 140, 150 , 160 were $143.9(2.49), 152.9(2.79), 161.6(3.02), 170.0(3.16), 177.8(3.25), 184.5(3.34)$, and 189.7 (3.45) $\mathrm{mmHg}$, respectively. However, the rate of elevation of SBP was zero at HR $175 \mathrm{bpm}$, which was calculated from the cubic regression equation. This may indicate that SBP is inhibited by baroreceptors and other factors at $H R$ above $170 \mathrm{bpm}$. There were no significant relationships between SBPs@HR 100 160 and indices of aerobic capacity such as maximal oxygen consumption or PWC 170. Double product (DP) as an index of oxygen consumption by cardiac muscle increased with HR without any reduction in its rate of elevation during exercise.
\end{abstract}

(Jpn. J. Phys. Fitness Sports Med. 1997, $46: 93 \sim 100)$

key words : aerobic capacity, baroreceptor, double product

\section{緒言}

軽症高血圧症に対する軽運動の効果が認められ るようになり ${ }^{13.17}$ 22,28), 安静時血圧の高い人々 が積極的に運動と取り組むようになってくること が予想される．血圧の上昇は心臓への負担増加で あり，高血圧症の人々には心臓に何らかの異常を 持っている可能性が高いので，常に運動時の血圧 応答をチェックして十分に注意することが必要で ある。

運動時の血圧変動については多くの研究報告が ある ${ }^{10,18.20 .25)}$ 。しかし，運動時に血圧が上昇す ることはわかっているが，心拍数 (HR)がいくつ の時に血圧がどの程度まで上昇するのか，またそ の上昇傾向として運動に伴い直線的に増加するの か, 曲線的なのか, 未だ明確にはされていない. 運動時の一過性の血圧応答は心拍出量と総末梢血
管抵抗に作用されると考えられる ${ }^{4)}$.さらに運動 により血圧が上昇し続けると大動脈弓や䅡動脈洞 の圧受容器による調節や代謝に伴う変化に応答す る化学受容器による調節を受けるということが考 えられる ${ }^{9.19)}$. Strange らは29)，サイクルエルゴ メータでの運動中に䫋動脈洞に $50 \mathrm{mmHg}$ の陰圧 をかけると，血圧は低下すると報告をしている。 このように運動中の血圧は物理的および化学的な 影響を受けて決定されることになるが、同一運動 負荷でも年齢や性によって血圧には差が見られる ことも報告されており ${ }^{8)}$, その值は個人の特性に より異なると予想される.

$\mathrm{HR}$ と収縮期血圧 $(\mathrm{SBP})$ の関係を先行研究から 検討してみると, Andersen et al. ${ }^{2)}$ は負荷が小さ い場合は血圧はほとんど変化せず，ある程度負荷 が増加してから血圧は上昇し始めることを報告し ている. Kiyonaga ら ${ }^{14)}$ は運動時のダブルプロダ
*徳島大学総合科学部行動科学 厂770 徳島市南常三島町1-1

**徳島大学医学部付属病院 厂770 徳島市蔵本町3-18-15
Faculty of Integrated Arts and Sciences, The University of Tokushima, Tokushima 770, Japan University Hospital, The University of Tokushima,Tokushima 770, Japan 
クトの変異点の存在について報告している。これ らは軽運動時の HR が低い時点で SBPに変異点 が存在する可能性を指摘している。.さらに血圧が

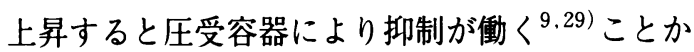
ら HR と SBP との関係において SBP は低圧と高 圧の 2 点で変異点を持つことを予想させる.

本研究の目的は SBP と HR との関係を検討し, これに基づいて運動中の血圧応答を調べ運動処方 に利用し得る知見を得ようとするものである.

\section{II. 実 臤 方 法}

\section{1. 被検者}

被検者は男子大学生 32 名で，その内訳はサッ カ一選手22名, 陸上選手 5 名, 水泳選手 1 名, 野 球選手 2 名, バスケットボール 1 名, そして運動 を行っていない者 1 名である．被検者の年齢，身 長, 体重, および Body Mass Index (BMI) の平均 值（標準偏差）は，それぞれ19.9 (1.12) 歳, $171.4(4.85) \mathrm{cm}, 63.6(6.31) \mathrm{kg}, 21.6$ (1.89) であっ た。また安静時 SBP と最大酸素攝取量 (HR と酸 素摄取量の関係より推定)の平均值 (標準偏差) は，それぞれ 121.0 (12.56) $\mathrm{mmHg}$ と 47.1 (5.59) $\mathrm{ml} / \mathrm{kg} / \mathrm{min}$ であった。これらの被検者について， 運動時の HR, SBP, 酸素摄取量および血中乳酸 濃度を測定した，実験は午後からとし，測定開始 予定の 3 時間前には食事を終え，また食後はでき るだけ安静状態をとるように指示した。 なお被検 者には事前に実験目的と内容を詳しく説明し，同 意を得た。

\section{2. 運動負荷法}

運動として電気制動式サイクルエルゴメーター によるペダリング運動を実施した。負荷には漸増 負荷法を用い, 3 分間安静座位後, 最初に 30 ワッ トの運動を 3 分間行った. その後も連続的に 3 分 間隔で30ワットずつ負荷を増加させ, 被検者が止 めたいと意志表示するまで行った。

\section{3. 測定項目及び方法}

心電図を胸部双極誘導で連続的に記録し, HR を心拍数モニターで常時監視した。血圧は各負荷 毎に 2 分10秒からマンシェット(カフ)に加圧して 測定を開始し，負荷の切り替わる10秒前までに測
定を終了した．聴診法による運動時の血圧測定 にはいろいろと測定精度の問題が指摘されてい $る^{15)}$. 血管内圧から記録した直接法は一拍動毎 の血圧を測定しているのに対して，聴診法では SBP と拡張期血圧 (DBP) は少なくとも数十秒は 異なる時点で測定することになり，その間に数十 拍動の差が生じることはどうしても避けられない 条件である、また，聴診法では血管音 (Korotkov 音 ; 以下 $\mathrm{K}$ 音) の第一音の小さいことや聴診間隙 が生じる27)こともあることから SBP の判定に誤 差を産む原因にもなっている，運動時の DBP は スワンの第 4 点といわれているが，それを瞬時に 判定することは困難である。これらのことが運動 時の聴診法による血圧測定の難しさであろうが, 本研究ではカフ圧と $\mathrm{K}$ 音を記録紙に記録してから 判定する聴診記録法 ${ }^{23)}$ を用いて測定精度を高め るよう配虑した。しかし，DBP についてはこの 測定法でも判定困難な例があったので，今回は SBP についてのみ検討した。

本装置による血圧測定を図 1 のようにおこなっ た，全被検者に対してカフを左上腕に装着し，そ の圧を圧トランスデューサー (PS-2 KB, 共和) によって記録した，K音を記録するために心音マ イクロフォン (MA-250, フクダ電子) を左时窩部 の上腕動脈の上部に固定し, 心音計により増幅し て記録した。水銀柱の高さを目測で読み, 10 $\mathrm{mmHg}$ 単位で手動によりマイクロスイッチをオ ン, オフさせて電気的シグナルを発生させ記録し た.これらのカフ压, $\mathrm{K}$ 音, $10 \mathrm{mmHg}$ 毎の水銀 柱の高さを示すシグナル，そして心電図の 4 つの 信号は, 電磁オシログラフ (ビジグラフ, NEC三 栄)に記録すると同時に, データレコーダ (A-44, SONY)にも記録した. その例を図 2 に示す.もし， ノイズのためSBP の判定が困難な場合には, デー タレコーダのテープ速度を変えて波形がよくわか るように再生して正確な SBP の判定を行えるよ うにした，尚，K音の第一音が現れた後，次の 1 〜2 拍動の部分で $\mathrm{K}$ 音が消失する (聴診間隙)こと もあるが，その場合でも K 音の第一音が現れた時 のカフ圧を SBP とした.

血中乳酸濃度は各負荷における血圧測定終了 


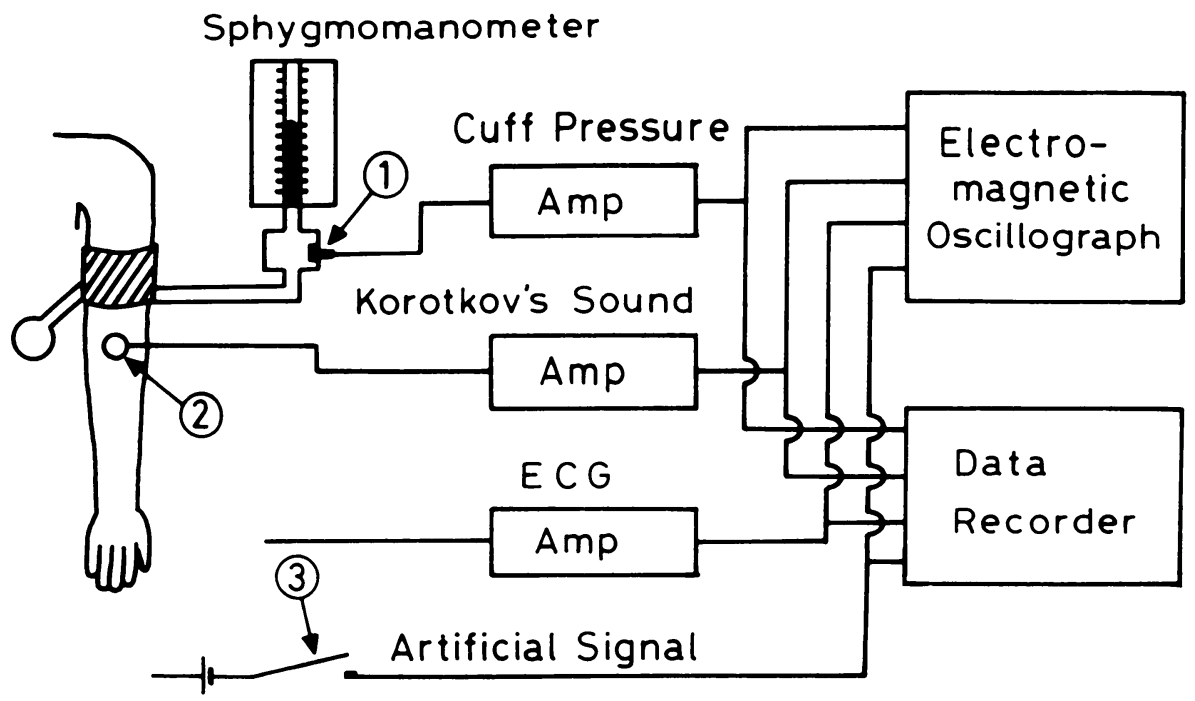

Fig. 1. An apparatus for measuring blood pressure.

1 , pressure transducer ; 2 , microphone ; 3 , microswitch.

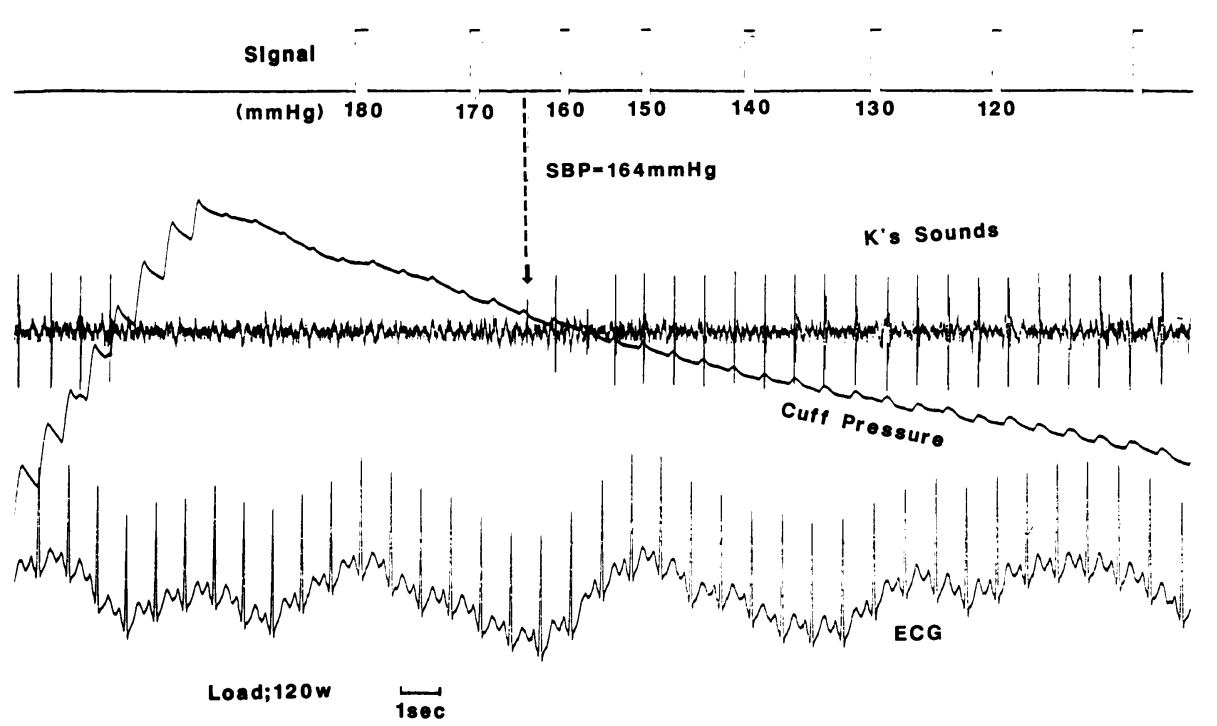

Fig. 2. A sample of simultaneous recording of Korotkov's sounds (K's sounds), electrocardiogram (ECG), cuff pressure and artificial signal. Numerals written below the signals are readings of the sphygmomanometer expressed in $\mathrm{mmHg}$. Exercise was performed as $120 \mathrm{w}$. Arrow indicates the first K's sound, and corresponding to the systolic blood pressure (SBP).

後，すぐに指尖に採血用針を刺し，毛細管に約 $40 \mu 1$ の血液を採集して直ちにラクテートアナラ イザー(YSI, model $23 \mathrm{~L}) て ゙$ 分析した.

酸素損取量は被検者に呼気マスクを装着させ, 呼吸代謝モニター（エアロモニター， AE-10)を用
いミキシング法により30秒間隔で運動終了まで連 続的に測定した。なお測定開始前に毎回標準ガス による測定装置の調整を行った，HR と酸素攝取 量を基に回帰式を求め, 年齢から最大 $\mathrm{HR}$ を推定 してそれに対応する酸素摂取量を最大酸素摂取量 
とした.

$\mathrm{HR}(\mathrm{X})$ と SBP $(\mathrm{Y})$ の関係については全被検者に おいて最小自乗法により回帰式を求めた。 その回 帰式を用いて HR が100，110，120，130，140, 150 ，および 160 拍/分の時の SBP を算出した。 それを SBP@HR＃と表記する．血中乳酸濃度と 酸素拱取量の関係は簡単な回帰式で表すことがで きないので市販のコンピュータソフトによるス ムージィング(カレイダグラフ,マッキントッシュ 対応)を行い, 乳酸濃度 $4 \mathrm{mM}$ の時の酸素攝取量 をグラフ上より読み取った。

統計処理において, 相関は Pearsonの相関係 数を求め危険率 $5 \%$ 水準を有意とし，また回帰式 は最小自乗法で求めた.

\section{III. 結 果}

\section{1. 収縮期血圧 $(\mathrm{SBP})$ の上昇パターン}

運動時の SBP は運動負荷の増加に伴い上昇し た. 全被検者32名の安静時のデー夕を除く運動時 の全データから HR と SBP の関係を検討するた めに 2 次および 3 次の回帰式を求めた。相関係数

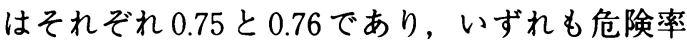
$1 \%$ 以内で有意な相関が見られた。 しかし，緒言 のところで述べたように先行研究から考えて SBP は, HR がある程度増加してから上昇し始め, また HR がかなり増加してくると SBP の上昇が 抑えられると推定されるが, この条件にあう傾向 を示したのは 3 次式であった. 2 次式では Xの 2 次の項が負となり，上に凸となる曲線を示し， HR が低い時点での SBP の変異点は見られず, HR の高いとこるで SBP が頭打ちになる傾向を 強調した曲線を示した。 3 次回帰式では HR が75 拍/分と175拍/分で SBP に変異点が見られ，HR が75拍/分を超えると SBP は急激に増加していく が, HR が175拍/分に達するとその増加率がゼロ になるという傾向を示した(図 $3 \mathrm{~A}$ 参照)。また各 個人毎に 3 次回帰式が適用できるかを検討した が，いずれも $1 \%$ 水準で有意であった。この結果 は運動時の HR-SBP 関係を示すのに 2 次式より も 3 次式の方が妥当であることを示している．図 3 Bには図の煩雑さを避けるために20名の被検者

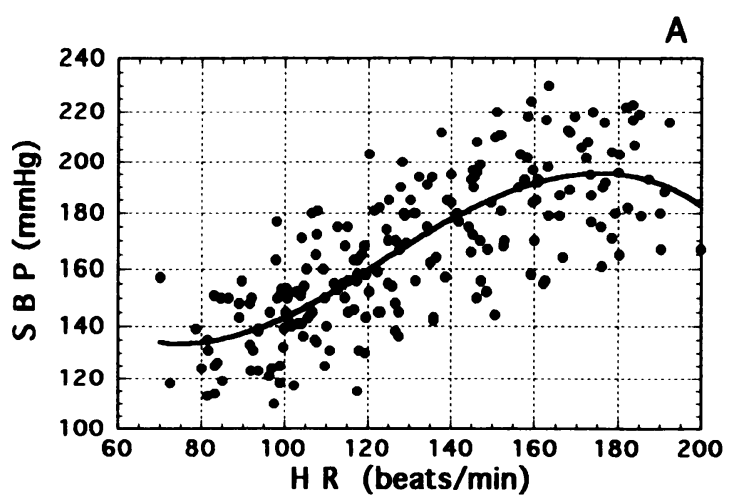

B

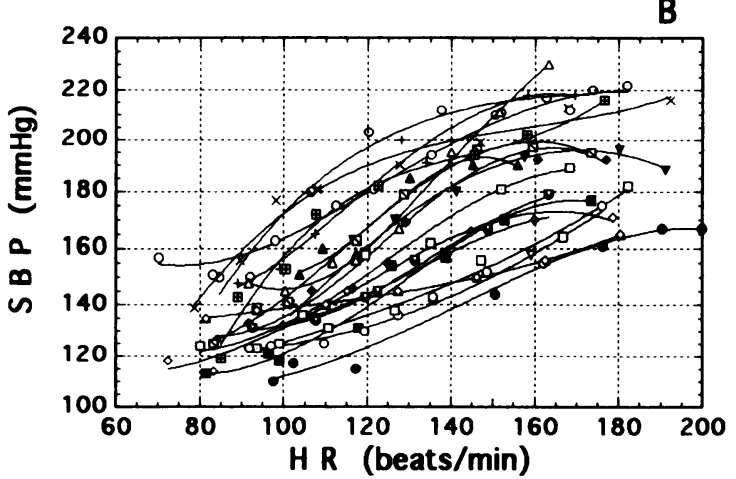

Fig. 3. A : Relationship between $H R$ and SBP in all subjects $(n=238, r=0.76, p<0.01) . B$ : Regression curves related to heart rate (HR) and systolic blood pressure (SBP) in 20 sub. jects. The regression curyes were drawn with cubic equations.

について個々の 3 次回帰曲線を示した.

この結果に基づき，健康な青年男子のペダリン グ運動時の平均的な SBP を得るために, 各被検 者毎の 3 次回帰式を用いて32名全員の実測の範囲 に近いHR 100〜160拍/分間における10拍ごとの SBP を推定し，それを表1に示した.SBP@HR 100 は $143.9 \mathrm{mmHg}$ で, SBP@HR 160 は $189.7 \mathrm{mmHg}$ と HR が100拍/分から 60 拍增加する間にSBP の 増加は $45.8 \mathrm{mmHg}$ であった。

2. 収縮期血圧 $(\mathrm{SBP})$ と有酸素的能力との関係

HR 100 160拍/分間での SBP@HR＃と有酸素 的能力の指標である体重当たりの推定最大酸素捸 取量, PWC 170 および乳酸濃度 $4 \mathrm{mM}$ 時の酸素 摂取量との間には有意な相関は見られなかった。

3. ダブルプロダクト (DP)の変動パターン 
Table 1. Mean value and SEM of systolic blood pressure (SBP) at heart rate of 100 $160 \mathrm{bpm}$.

\begin{tabular}{|c|c|c|c|c|c|c|c|}
\hline & SBPEBR 100 & SBPEER110 & SBPERR120 & SBPEBR130 & SBP PGR 140 & SBPQER150 & SBPEAR160 \\
\hline $\operatorname{mean}(\operatorname{mmBg})$ & 143.9 & 152.9 & 161.6 & 170.0 & 177.8 & 184.5 & 189.7 \\
\hline SEM & 2.49 & 2.79 & 3.02 & 3.16 & 3.25 & 3.34 & 3.45 \\
\hline
\end{tabular}

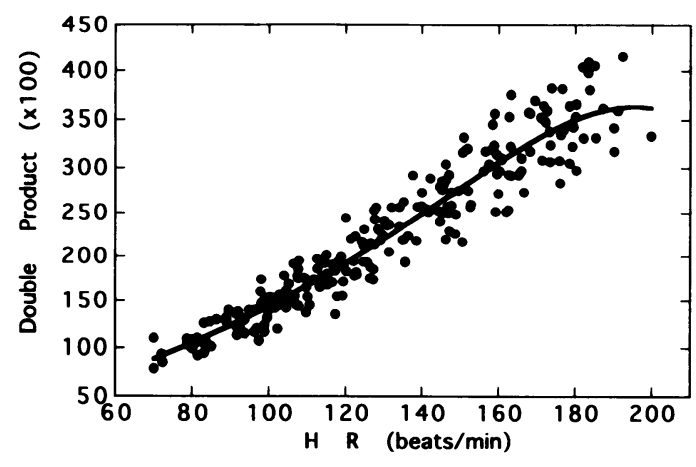

Fig. 4. Relationship between heart rate and double product (the product of heart rate and systolic blood pressure) $(n=238, r=0.95$, $\mathrm{p}<0.01)$. The regression curve was drawn with quartic equation.

$\mathrm{SBP}$ と HR の関係が 3 次式であるので, DP は HR の 4 次式で表すことができる. それを図 4 に 示したが, 全体として本実験での測定範囲である HR 80〜 190拍/分の間では DP は増加傾向を示し た。個人毎に検討すると HR の低い時点で変異点 が見られたのは32名中13名で，他の19名について は確認できなかった。 また HR の高い時点で SBP のように頭打ち現象が明らかに確認できた のは 5 名であった.

\section{N. 考}

察

運動時の血圧測定を聴診法でおこなうことには 問題があることはすでに指摘されている SBP はK 音の第一音が聞こえたときの水銀柱の 高さとされているが, 聴診間隙が存在する ${ }^{27) こ ~}$ ともあり従来の聴診法で運動時の SBP を決定す るのは測定精度上問題がある。 それで本研究では 聴診法に従ってはいるが, 判定に必要なカフ圧, 血管音，心電図，そして水銀柱の高さを同時に記 録し，かつノイズの混入が大きい場合はデータレ コーダからの再生により血管音を正しく判定する
方法を用いた，先行研究において観血的方法で血 管内圧を測定して求めた SBP と聴診法による $\mathrm{SBP}$ とは有意な相関があると報告されており 15 . 21.25), また一般的に安静時も運動時も聴診法で SBP の測定がなされているので, 本研究の結果 は実用的な価值があると言える.

血圧は心拍出量, 末梢血管抵抗, 血液量, 血液 の粘性そして血管の硬さに影響されるが，これら の作用因子の中で特に一過性の運動に影響される ものは心拍出量と末梢血管抵抗の 2 つであり, 血 液量, 血液の粘性および血管の硬さは短時間の間 に血圧値に変動をもたらすほど変化するとは考え られない4．よって本研究でおこなった 30 分以内 の漸増負荷運動での SBP の変動は主として心拍 出量と末梢血管抵抗が変化したために生じたと推 定してよいであろう．運動時には交感神経の緊張 増加や血中ノルエピネフリン濃度の増加 ${ }^{6.26)} に よ$ り血管系に収縮が起こると考えられるが，実際に は総末梢血管抵抗は運動強度の増大と共に隇少す

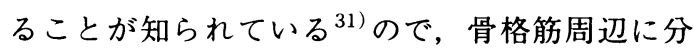
布する血管系では炭酸ガスの増加, 酸素の減少, 乳酸の増加などにより搪張作用が現れ, 結果的に は血管系全体として断面積が大きくなっていると 考えられる ${ }^{5)}$.

先行研究 ${ }^{2.14)}$ から推定して, SBP は軽強度では 上昇率は小さく, 強度がある程度まで高まってか ら上昇傾向が現れ，さらに血圧が過度に上昇する と圧受容器の興奮が高まり交感神経活動を抑制す

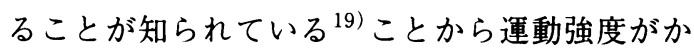
なり高くなると血圧の増加傾向は抑制されると考

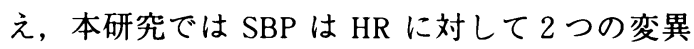
点を持つと仮定した。この仮説を説明できる式は 3 次式であるので32名の被検者についてこの回帰 式の妥当性を検討した結果, 各被検者毎の回帰式 においても，また被検者全員のデータについての 
回帰式においても非常に高い有意な相関が見られ た。2次式についても検討した，2次式でも有意 な相関はみられるが, 個々の例をみると HR の 2 次の項が負となった場合 HR の高い時点では SBP が頭打ちになるという傾向には適合するが $\mathrm{HR}$ が低い時点での急激な SBP の上昇傾向には 適合しない例や 2 次の項が正となった場合には SBP の明らかな頭打ち現象に適合しない例がみ られ，全体として共通する回帰式は 3 次式である ことがわかった.

3 次回㷌式における SBP の第一および第二の 変異点の $\mathrm{HR}$ はそれぞれ 75 拍/分と 175 拍/分で あった。しかし，HR75拍/分はかなり低い HR であり実際第一負荷の30ワットで80拍/分以下の HR を示したものは 3 名であり，また個々の被検 者のデー夕からみて明確な第一変異点を見い出す ことは困難であった. Saito and Nakamura ${ }^{26)}$ は最 大酸素摂取量の $18.7 \%$ (HR 75.3 拍/分に相当) から 42.9\%（HR 105.0 拍/分に相当）の強度にかけて運 動時の交感神経活動や副交感神経活動の指標が変 化することを報告している. 図 3 からその傾向を 窥うことができるが, 運動時の HR が低い時点で 自律神経等の作用により SBP の上昇傾向に変化 がおこる可能性は十分考えられる. 図 3 B の中で はじめから SBP が上昇している例もあるがこれ らは HR が80拍/分以上であり，もっと低い $\mathrm{HR}$ での SBP を計測すればなだらかな上昇傾向が見 られるのか, あるいはそのような傾向を示さない 例もあるのか検討する必要がある。一方, 圧受容 器の活動による心臓血管系への作用として SBP の上昇が抑制されることが知られている が ${ }^{19.29)}$ ，ヒトにおいて運動により HR がどの程 度まで増加したときに SBP の上昇が抑制される かということはまだ不明である．この点を検討す るために全データでの HR と SBP の回帰曲線か ら変異点を求めると, それは $\mathrm{HR}$ が 175 拍/分の ときであった。しかし，個人毎に見るとSBP の 変異点の現れるポイントには差がある. 被検者 32 名中11名では変異点の存在を確認できなかった が，21名の被検者では HR が 140〜190拍/分の間 で SBP の上昇率抑制の傾向が見られた。その内
の10名の被検者では負荷の最後の 3 段階において SBP がほほ同じか最後の負荷で僅かに低下する という結果も得られた。このように運動時に圧受 容器などによる血圧の調節機構が働き出すポイ ントには個人差があるが, 平均的には HR が 175 拍/分付近であるという点が明らかになった。

本研究で得られた 3 次回帰式から男子大学生に おける HR 100 拍/分から 10 拍刻みで 160 拍/分ま での各 SBP の平均値を求めた（表 1 ). 年齢層が 限られてはいるが, ペダリング運動において各 HR で SBP がどの程度まで上昇するかを示した のは本研究の知見の一つである．それらを同年齢 の被検者を対象としてほほ同じ方法で測定した生 山ら ${ }^{10)}$ の報告と比較した。生山らは非鉎練者に ついて HR 102 拍/分で SBP $133.1 \mathrm{mmHg}$ (本実験 での 3 次回帰式から求めた同一 HR での SBP は $144 \mathrm{mmHg}$, 以下同じ), および 138.9 拍/分で $154.4 \mathrm{mmHg}$ (本実験では $177 \mathrm{mmHg}$ ) という值を, また鍛練者については HR 98.3 拍/分で 154.0 $\mathrm{mmHg}$ (本実験では $142 \mathrm{mmHg}$ ) および 140.3 拍/分 で $203.7 \mathrm{mmHg}$ (本実験では $178 \mathrm{mmHg}$ )という値 を得ているが，本実験で得た結果は両者のほほ中 間の値に相当することがわかった。一方, Miyazawa and Yamaguchi ${ }^{18)}$ は19才から37才の男子20 名について，仰臥位でのペダリング運動時に観血 的方法で上腕動脈で血圧測定を行い，HR 100 拍/ 分で SBP は $143 \mathrm{mmHg}$ (本害験では $143 \mathrm{~mm} \mathrm{Hg}$ ), 134 拍/分で $172 \mathrm{mmHg}$ (本実験では $172 \mathrm{mmHg}$ ), 155 拍/分で $187 \mathrm{mmHg}$ (本実験では $189 \mathrm{~mm} \mathrm{Hg}$ ) と いう平均值を報告しており，本研究の結果とは測 定方法と測定時姿勢の違いにも関わらずほほ同じ である．生山らは被検者の体力差を考慮してグ ループ分けしているが, 本研究の結果は HR が 100 ～ 160 拍/分での SBP と推定最大酸素搷取量 などの有酸素作業能力の指標との有意な相関は見 られなかった。また Miyazawa and Yamaguchi の 被検者は鍛錬者ではないが, 本研究の被検者が銭 錬者に位置づけられるにも関わらず, SBP は同 じ值であった。よって運動時の同一 HR における SBP を決定する要素は体力水準とは無関係であ ると考えられる. しかし, 田中 ${ }^{30)}$ は長期のトレー 
ニングに伴い，血液量が増加する可能性を指摘し てるので，今後個人の身体的特性により運動時の SBP がどのように変化するのか詳しく検証して いく必要がある.

アメリカスポーツ医学会 (ACSM) は運動負荷テ ストで SBP が $225 \mathrm{mmHg}$ 以上，あるいは DBP が $90 \mathrm{mmHg}$ 以上に上昇した場合を異常反応と定 義し, SBP $250 \mathrm{mmHg}$ 以上，あるいは DBP 120 $\mathrm{mmHg}$ 以上になったときにはテストを中止するよ う勧告している1)。本実験においては被検者が健 康な青年であったため, SBP が $250 \mathrm{mmHg}$ を越 えたものはいなかった．本研究での SBP の最高 值として, HR が 163 拍/分の時に $230 \mathrm{mmHg}$ と いう例があった，松井らもこの様な例を報告して いる ${ }^{16)}$ 。さらに中高年者のジョギングにおいて も $200 \mathrm{mmHg}$ を超えた者がいたという報告があ $3^{3,11,32)}$.

Miyazawa and Yamaguchi ${ }^{18)}$ は前述の論文の中 で, 70才から78才の 7 名の平均で, HR 105 拍で SBP は $210 \mathrm{mmHg}$ とかなり高い值を報告してい る. 加齢や疾病に伴う安静時血圧上昇が運動時の SBP 上昇パターンにどのように影響するのか, この点についても今後検討する必要がある.

SBP と HR の積であるダブルプロダクト (DP) と心筋の酸素消費量との間に相関が認められる 13)ことから, 運動時の DP の変化をとらえるこ とは運動処方の作成上，重要なことである．HR と DP の関係は図 4 に示したように HR の増加と 共にDP は上昇を示した。このことは運動強度の 増加に伴い，心筋の酸素消費量も増加しつづける ことを示唆していると考えられるが，高い HR に おいて SBP のようにDPに頭打ち現象の見られ た 5 名の被検者で心筋の酸素消費量も頭打ちに なっているのか否かについて興味の持たれること であるが本研究ではその点は明らかにできない.

\section{V. を め}

32名の男子大学生を被検者として，3 分間隔の 漸増負荷法によるぺダリング運動を実施し，次の 結果を得た。

1）SBPは運動強度の増加と共に上昇し，HRに
対する 3 次式によく適合した。その式より変異 点を求めると $\mathrm{HR}$ が 75 拍/分と 175 拍/分で あった。すなわち運動強度に伴う HR の増加が みられても SBP の上昇には頭打ち現象がある ことを示した。

2） HR が100から 160 拍/分までの10拍間隔の SBP 值はそれぞれ144，153，162，170，178， 185, そして $190 \mathrm{mmHg}$ であった.

3）SBP@HR 100〜160 と有酸素的作業能力との 有意な相関はみられず, ペダリング運動時の血 圧調節機構は有酸素的作業能力とは無関係に働 いていることが示唆された。

4） DP は運動に伴う HR の増加に比例して増大 する傾向を示し, SBP のような頭打ち現象を 示したのは 5 名であった.

（受理日 平成 8 年10月 9 日）

\section{文}

\section{献}

1) American College of Sports Medicine. Guideline for Exercise Testing and Prescription, 4 th ed. (Pate R. R. et. al. ed.), Lea \& Febiger, Philadelphia, (1991), 55-91.

2) Andersen, P., Adams, R. P., Sjogaard, G., Thorboe, A., and Saltin, B.. Dynamic knee extension as model for study of isolated exercising muscle in humans. J. Appl. Physiol., (1985), 59(5) : 1647-1653.

3）麻生 幸. 外科入院患者のトレッドミル運動負荷 時血圧応答とその意義, 体力科学, (1988), 37, 367-375.

4) Ȧstrand, P-O. and Rodahl, K., Textbook of Work Physiology. 3 rd. ed. McGraw-Hill, New York, (1986), 144-202.

5) Folkow, B. and Neil, E. 著, 入内島十郎訳. 循環, 真興交易医書出版部，東京，(1973），256-272.

6）藤井宣晴, 鍋倉賢治, 権 五晨, 山崎文夫, 本間 幸子, 池上晴夫. 運動強度に対する心拍数および 血槳カテコールアミンの応答. 体力科学, (1992), 41, 313-321.

7) Galbo, H., Hormonal and Metabolic Adaptation to Exercise. Georg Thieme, Verlag. Stuttgart. New York, (1983), 2-27.

8) Gleim, G. W., Stachenfeld, N. S., Coplan, N. L., and Nicholas, J. A., Gender differences in the systolic blood pressure response to exercise. Am. Heart J. (1991), 121, 524-530.

9）外須美夫. 圧受容器, 化学受容器反射による静脈 還流量の調節, Cardiac Practice, (1993), 4, 323328.

10）生山 匡, 荒尾 孝, 今野廣隆, 片岡幸雄, 和田 光明, 佐野裕司, 小山内博. 中高年者, 青年長距 
離走鉎練者及び一般青年の運動中の血圧変動, 体 力研究, (1979)，42, 34-46.

11）片岡幸雄, 生山 匡, 和田光明, 佐野裕司, 今野 廣隆, 川村協平, 渡辺 剛, 西田明子, 小山内博. 中高年高血圧者の長時間ランニングに伴う血圧変 動, 体力研究, (1985), 60, 13-24.

12) Kitamura, K., Jorgensen, C. R., Gobel, F. L., Taylor, H. L., and Wang, Y., Hemodynamic correlates of myocardial oxygen consumption during upright exercise. J. Appl. Physiol., (1972), 32, 516-522

13) Kiyonaga A., Arakawa K., Tanaka H., Shindo M., Blood pressure and hormonal responses to aerobic exercise. Hypertension, (1985), 7, 125-131.

14) Kiyonaga A., Brubaker, P. H., Tanaka, H., Matrazzo, B., Pollock, W. E., Shindo, M., and Miller, H. S. JR., Determination of ventilatory threshold using double product during ramp treadmill testing of cardiac patients. Proceedings of FISU/CESU conference. The 18 th Universiade 1995 Fukuoka, (1995), 456457.

15) Lightfoot, J. T., Can blood pressure be measured during exercise? A review. Sports Medicine, (1991), 12, 290-301.

16）松井 健. 運動と血圧, 保健の科学, (1995), 37. 370-377.

17）三浦伸一郎, 荒川規矩男. 高血圧の運動療法, か らだの科学 [増刊] 高血圧, (1993), 112-116.

18) Miyazawa K. and Yamaguchi, I., Cardiovascular response to exercise in the healthy male septuagenarians: With reference to plasma norepinephrine. Tohoku J. Med., (1984), 143, 177-183.

19）森田啓之, 細見 弘. 交感神経活動の調節機構と 心䑏血管中枢, Cardiac Practice, (1993)，4,257261

20）本山 貢, 角南良幸, 木下藤寿, 入江 尚, 清永 明, 田中宏暁, 進藤宗洋. Lactate threshold を指 標とした長期トレーニングとその中止が薬物療法 下の高血圧症患者の血圧に及ほす影䈏について, 体力科学, (1994), 43, 300-308.

21) Nelson, R. R., Gobel, F. L., Jorgensen, C. R., Wang, K., Wang, Y., and Taylor, H. L., Hemodynamic pre- dictors of miocardial oxygen consumption during static and dynamic exercise. Circulation, (1974), 50 , 1179-1189.

22）虑 昊成, 田中喜代次, 竹田正樹, 海野英哉, 檜 山輝男．本態性高血圧症女性に対する運動療法の 血圧および活力年龄への効果, 体力科学, (1996), 45, 91-100.

23) Obara, S., Yamaguchi, H., Bando, E., and Miyamoto, H., An auscultatory recording method for blood pressure measurement during exercise. Jpn. J. Physiol., (1987), 37, 757-760.

24) Palatini P., Blood pressur behaviour during phy. sical activity. Sports Medicine, (1988), 5, 353-374.

25) Robinson, T.E., Sue, D. Y., Huszczuk, A., WeilerRavell, D., and Hansen, J. E., Intra-arterial and cuff blood pressure responses during incremental cycle ergometry. Med. Sci. Sports Exerc., (1988), 20, 142149.

26) Saito, M. and Nakamura, Y., Cardiac autonomic control and muscle sympathetic nerve activity during dynamic exercise. Jap. J. Physiol., (1995), 45, 961-977.

27）芝山秀太郎, 江橋 博. コロトコフ音の聴診間隙, 体力研究, (1977), 36, 16-25.

28）進藤宗洋，田中宏暁，田中 守，山内美代子．高 血圧の運動療法, 体育の科学, (1989), 39, 105-110.

29) Strange, S., Rowell, L. B., Christensen, N. J. and Saltin, B., Cardiovascular responses to carotid sinus baroreceptor stimulation during moderate to severe exercise in man. Acta Physiol. Scand., (1990), 138. 145-153.

30）田中宏暁. 運動による血圧降下と体液因子の変化, 体育の科学, (1992), 42, 174-180.

31) Torok, D. J., Duey, W. J., Bassett, JR., D. R., Howley, E. T., and Mancuso, P.. Cardiovascular responses to exercise in sprinters and distance runners. Med. Sci. Sports Exerc., (1995), 27, 1050-1056.

32) 渡辺郁雄, 宮本洋通, 諸岡一泰. 中高年ジョギン グ愛好家における運動負荷時にみられる循環諸量 の変化の特性, 臨床スポーツ医学, (1993), 10, 1250-1255. 